\title{
MECHANISMS OF HARDNESS INCREASE FOR COMPOSITE SURFACE LAYERS DURING LASER GAS NITRIDING OF THE Ti6A14V ALLOY
}

\author{
MEHANIZMI POVEČANJA TRDOTE POVRŠINSKIH SLOJEV \\ KOMPOZITOV ZLITINE Ti6AI4V MED LASERSKO-PLINSKIM \\ NITRIRANJEM
}

\author{
Aleksander Lisiecki \\ Silesian University of Technology, Faculty of Mechanical Engineering, Welding Department, Konarskiego 18A, 44-100 Gliwice, Poland \\ aleksander.lisiecki@polsl.pl \\ Prejem rokopisa - received: 2016-06-14; sprejem za objavo - accepted for publication: 2016-12-14
}

doi:10.17222/mit.2016.106

\begin{abstract}
Titanium matrix composite (TMC) $\mathrm{TiN}_{\mathrm{X}} / \mathrm{Ti}$ surface layers characterized by high microhardnesses in a range from $1000 \mathrm{HV} 0.2$ up to 2330 HV0.2 were produced by the Laser Gas Nitriding (LGN) of Ti6Al4V substrate in a pure nitrogen environment by a diode laser beam with unique characteristics. Despite the high hardness, crack-free surface layers were produced in a wide range of processing parameters. It was found that the maximum values of hardness and its depth profile on the cross-section of the surface layer should be considered in relation not only to the population and volume fraction of the dendritic precipitations of titanium nitrides $\mathrm{TiN}$, but also in relation to the atomic ratio $\mathrm{N} / \mathrm{Ti}$ in the $\mathrm{TiN}_{\mathrm{X}}$ compounds. Conditions favorable for stoichiometric $\delta$-TiN nitrides precipitation exist in the vicinity of the liquid/gaseous nitrogen boundary, because of the highest temperatures in this region of melt pool and the highest concentration of atomic nitrogen. Therefore, the population of stoichiometric titanium nitrides is the highest directly under the top surface.
\end{abstract}

Keywords: laser gas nitriding, titanium alloy, diode laser, metal-matrix composite, hardening

Nitriranje kompozita na osnovi titana (angl. TMC) $\mathrm{TiN}_{\mathrm{X}} / \mathrm{Ti}$, za katere je značilna visoka mikrotrdota v območju med $1000 \mathrm{HV}$. in $2330 \mathrm{HV}_{0.2}$, je bilo izvedeno s plinskim laserskim nitriranjem (angl. LGN) na substratu zlitine Ti6Al4V s specialnim diodnim laserskim snopom. Kljub visoki trdoti, so površinske plasti proizvedene brez razpok v širokem območju procesnih parametrov. Ugotovljeno je bilo, da je potrebno upoštevati mejne vrednosti trdote in globino profila na preseku površinskega sloja $v$ povezavi, ne samo s količino in volumskim deležem dendritov titanovih nitridov (TiN), pač pa tudi z atomskim razmerjem N/Ti v TiN $N_{X}$ spojinah. Najugodnejši pogoji za izločanje stehiometričnih $\delta$-TiN nitridov obstajav bližini meje talina/plinasti dušik. Tam so najvišje temperature in zato nastaja bazenček staljene kovine v prisotnosti najvišje atomske koncentracije dušika. Zato je količina nastalih stehiometričnih titanovih nitridov najvišja tik pod površino.

Ključne besede: lasersko-plinsko nitriranje, titanova zlitina, diodni laser, kovinska kompozitna matrica, utrjevanje (kaljenje)

\section{INTRODUCTION}

Titanium and titanium alloys, in particular, show great mechanical properties, especially strength-toweight ratio and corrosion resistance in different environments, compared to other advanced metallic or composite materials such advanced high-strength steels (AHSS), stainless steel, nickel- or cobalt-based superalloys, aluminium or magnesium alloys. ${ }^{1-6}$ Titanium alloys also show good resistance to static, dynamic, and cyclic alternating loads (fatigue), such as in the case of vibrations. $^{7-11}$ One of the most commonly used twophase titanium alloys is the $\alpha+\beta$ alloy Ti6Al4V, the properties of which can be controlled through a heat treatment used to adjust the amounts and types of phases. ${ }^{12-16}$ However, the application of titanium alloys is often limited due to medium or even poor tribological properties. ${ }^{1,3,17-22}$ For that reason different surface treatments or surface-modification methods are often applied to improve the surface characteristic of Ti alloys, such hardness, erosion, friction, cavitation wear resistance, or even to improve the corrosion resistance..$^{1,23-27}$ One of such methods is the Laser Gas Nitriding of a titanium substrate in the solid or liquid state, by Laser Surface Melting (LSM) in a nitrogen-rich atmosphere or in pure gaseous or even liquid nitrogen (cryogenic conditions). ${ }^{1,24-27}$ In the field of Laser Gas Nitriding of titanium and its alloys, a lot of research has already been done. Laser nitriding of titanium substrate leads to the precipitation of hard titanium nitrides TiN in the metallic matrix, increasing hardness of the substrate surface. Additionally, the wear and also corrosion resistance of the substrate can be significantly increased, as shown by many studies and many researchers. ${ }^{1,3,11-14,24-27}$ However, the main problem widely reported is cracking of hard nitrided layers due to excessive hardness and stresses, especially in the case of multi-bead surface layers, when the subsequent layers are produced by overlapping. ${ }^{1,26-29}$ Thus, the control of hardness is crucial to ensure high quality and appropriate service properties of the laser nitrided surface layers. ${ }^{1} \mathrm{~S}$. Mridha and T. N. Baker ${ }^{25}$ produced hard a surface layers with a maximum surface hardness of $1480 \mathrm{HV}$ by laser 


\section{A. LISIECKI: MECHANISMS OF HARDNESS INCREASE FOR COMPOSITE SURFACE LAYERS ...}

melting a Ti6Al4V substrate in pure nitrogen environment. They found that the hardness is related to the dendritic TiN population (concentration) in the layers. Additionally, they indicate that the microstructure and thus the surface hardness can be controlled by nitrogen flow rates and laser energy density. In turn, C. Hu and T. N. Baker $^{26}$ produced crack-free overlapped nitrided layers, and they indicate that the tendency to crack is related to the volume fraction of titanium nitrides formed in the melt. They point to the importance of preheating the substrate before nitriding, which can reduce the tendency to crack and improve the depth profile. ${ }^{26} \mathrm{M}$. S. Selamat et al. ${ }^{27}$ successfully produced crack-free overlapped nitrided surface layers on a Ti6Al4V substrate in a dilute nitrogen atmosphere comprising $20 \%$ nitrogen and $80 \%$ argon. However, the surface hardness was rather in the medium range, from only $500 \mathrm{HV}$ to $800 \mathrm{HV}$.

In this study, a High Power Direct Diode Laser (HPDDL) with unique characteristics of the laser beam was applied for the surface melting of the Ti6Al4V alloy in a pure gaseous nitrogen environment at different scanning speeds and different laser output powers. Microhardness depth profiles were determined on the cross-section of the surface layers, while the structure, chemical and phase compositions were determined and analyzed.

\section{EXPERIMENTAL PART}

The tests of Laser Gas Nitriding were carried out on a substrate of the titanium alloy Ti6Al4V (Grade 5 according to ASTM B265), with the nominal chemical composition of $6.29 \mathrm{Al}, 4.12 \mathrm{~V}, 0.14 \mathrm{C}, 0.18 \mathrm{Fe}$ in $\%$ of mass fractions and balance Ti. This titanium alloy is comprised of a hexagonal close-packed (hcp) $\alpha$ phase and a body-centered cubic (bcc) $\beta$ phase, at room temperature, thanks the addition of vanadium that stabilizes the $\beta$ phase. The desired properties of this Ti-alloy are

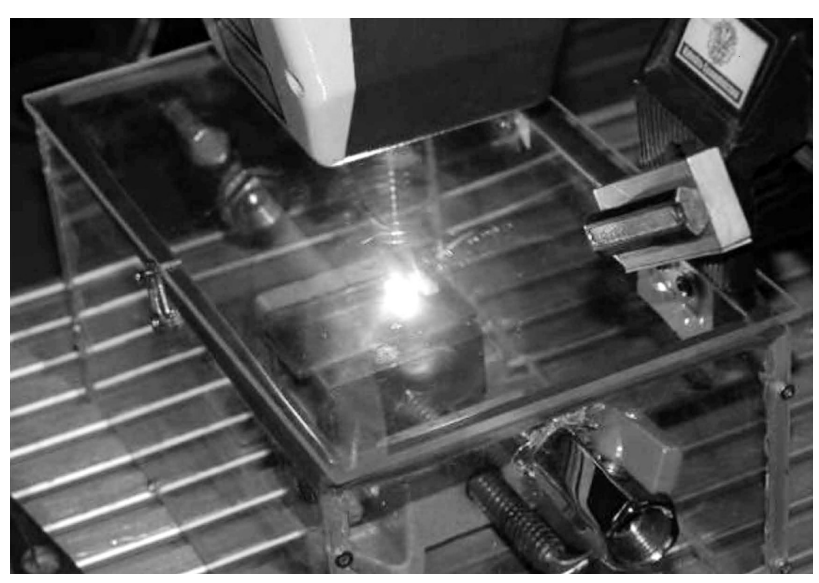

Figure 1: A view of laser melting of Ti6Al4V alloy substrate in the gas chamber filled with nitrogen by the HPDDL laser beam transmitted via the transparent cover made of acrylic glass (PMMA) shaped during the heat treatment. The samples prepared for nitriding tests were $3.0 \mathrm{~mm}$ thick and cut from a hot-rolled sheet into coupons of $40.0 \mathrm{~mm} \times 70.0 \mathrm{~mm}$. The whole surfaces of specimens were mechanically ground using 180-grade $\mathrm{SiC}$ paper to remove the surface oxide layers and to ensure uniform conditions for the absorption of laser radiation. Next the surfaces were decreased by acetone. The experimental setup was based on a fully automated and programmable positioning system coupled with a High Power Direct Diode Laser (HPDDL) with a rectangular beam spot. In the design of direct diode laser, the beam is emitted directly from the laser head, without the need to transmit a laser beam. In this case the generator of the laser radiation, shaping, and focusing optics are placed in a compact laser head. The laser head was mounted on a linear drive, set in a vertical position. The characteristic features of the specific HPDDL laser is a rectangular beam spot with dimensions of $1.8 \mathrm{~mm} \times 6.8 \mathrm{~mm}$, multimode energy distribution in the longitudinal direction, and a short wavelength of $808 \mathrm{~nm}$, which is advantageous because of the high absorption coefficient on the surfaces of metals. The rectangular beam spot was focused on the top surface of a sample and set transversely to the scanning direction. Single stringer beads were produce as a result of surface melting in the pure gaseous nitrogen. Due to the width of $6.8 \mathrm{~mm}$, the width of the stringer beads was in a range from approximately $6.0 \mathrm{~mm}$ to $6.5 \mathrm{~mm}$ wide. To provide stable and reproducible conditions of laser nitriding, and also to prevent the access of oxygen, or hydrogen from the ambient air, as well as the problem with degassing of the substrate a gas chamber was applied with a continuous flow of gaseous nitrogen at a pressure slightly higher than atmospheric pressure of about 1.0 bar. The gas chamber was first evacuated and next filled with gaseous nitrogen at room temperature. The nitrogen of $99.999 \%$ purity was delivered by an inlet placed on a side wall, and the free flow of nitrogen was provided via the chamber and through the outlet placed on the opposite side wall. The nitrogen flow rate was kept at $10.0 \mathrm{~L} / \mathrm{min}$. The gas chamber was made of acrylic glass (PMMA), which is completely transparent for the $808 \mathrm{~nm}$ radiation, so the laser beam was delivered into the chamber through the cover glass (Figure 1).

Table 1: Parameters of laser gas nitriding of the Ti6Al4V alloy by the HPDDL laser

\begin{tabular}{|c|c|c|c|c|}
\hline $\begin{array}{c}\text { Surface } \\
\text { layer }\end{array}$ & $\begin{array}{c}\text { Scanning } \\
\text { speed } \\
(\mathrm{mm} / \mathrm{min})\end{array}$ & $\begin{array}{c}\text { Laser out- } \\
\text { put power } \\
(\mathrm{kW})\end{array}$ & $\begin{array}{c}\text { Energy } \\
\text { input } \\
(\mathrm{J} / \mathrm{mm})\end{array}$ & $\begin{array}{c}\text { Power } \\
\text { density } \\
\left(\mathrm{W} / \mathrm{cm}^{2}\right)\end{array}$ \\
\hline SL1 & 400 & 1.8 & 270 & $1.5 \times 10^{4}$ \\
\hline SL2 & 1000 & 1.5 & 90 & $1.2 \times 10^{4}$ \\
\hline SL3 & 1500 & 1.5 & 60 & $1.2 \times 10^{4}$ \\
\hline
\end{tabular}

Processing parameters were chosen based on previous investigations in such a way as to provide different penetration depth, different thermal conditions of nitriding, and thus different structures and morphologies 


\section{A. LISIECKI: MECHANISMS OF HARDNESS INCREASE FOR COMPOSITE SURFACE LAYERS ..}

of the test surface layers. In general, the higher the energy input of the laser nitriding, the higher the penetration depth. Preliminary tests have shown that when using the HPDDL laser beam, preheating of the substrate is not required. The processing parameters and technological conditions are given in Table 1. After the nitriding trials, the samples were sectioned and grinded by 180 up to 1500 grit $\mathrm{SiC}$ abrasive papers and polished by $0.5 \mu \mathrm{m}$ diamond paste. Kroll's reagent was applied to reveal the microstructure on polished cross-sections. The composition, crystal structure and microstructure of the test surface layers were analysed by optical microscopy (OM), scanning electron microscopy (SEM), energy-dispersive spectroscopy (EDS), electron backscatter diffraction (EBSD), and X-ray diffraction (XRD). Vickers microhardness was measured along the symmetry axis of cross-sections, and the microhardness depth profiles were determined. The hardness values in specific regions of surface layers were correlated with the microstructures. The results of the investigations are given in Figures 2 to 8 .

\section{RESULTS AND DISCUSSION}

The surface layers produced by the HPDDL laser surface melting of Ti6Al4V substrate in a pure nitrogen environment are shiny and have a golden colour. The surface topography, depth of the fusion zone, and morphology are dependent on the processing parameters, such as scanning speed and the laser output power. Vickers microhardness depth profiles were determined with a load of $200 \mathrm{~g}$ on the cross-sections, starting from the subsurface region, through the fusion zone, heat affected zone, to the base metal, as shown in Figure 2. As can be seen, the maximum values of the microhardness were determined in the subsurface regions of every tested surface layer. However, the highest value of microhardness $2330 \mathrm{HV} 0.2$ was measured for the surface layer (SL1) produced at the highest energy input $270 \mathrm{~J} / \mathrm{mm}$, and the lowest scanning speed $400 \mathrm{~mm} / \mathrm{min}$ (Table 1, Figure 2). In this case the maximum depth of the fusion zone was estimated at approximately $1.6 \mathrm{~mm}$. As can be

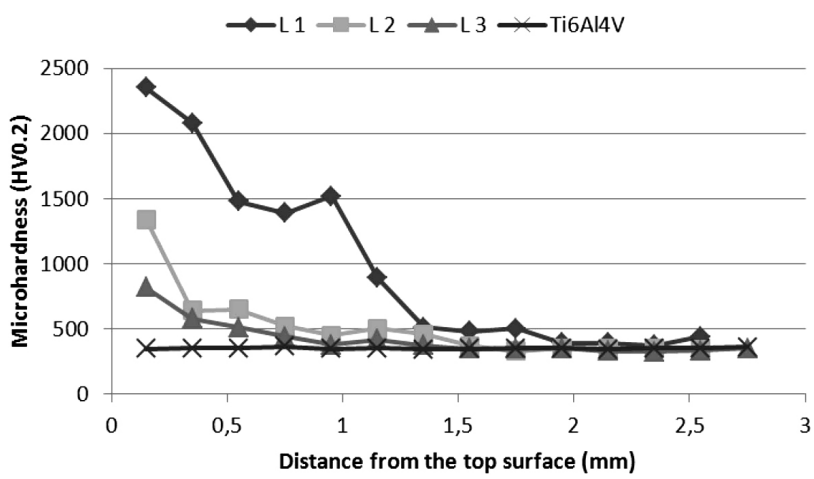

Figure 2: Microhardness profiles determined on cross-sections of nitrided surface layers compared to the substrate of Ti6Al4V alloy seen in Figures $\mathbf{3}$ to $\mathbf{5}$ the fusion zone is not homogeneous, and it can be divided into subregions. These results are consistent with the previous investigations described in ${ }^{1}$. The first subsurface region A extends to a depth of $150 \mu \mathrm{m}$ and consists of densely packed dendrites perpendicular to the top surface (Figure 3). However, some of these dendrites reach deeper, up to a depth of $250 \mu \mathrm{m}$ or even $300 \mu \mathrm{m}$, (Figures 3, 4). It is also worth nothing that the surface (SL1) is flat, as shown in Figure 3a. The surface is covered tightly by a
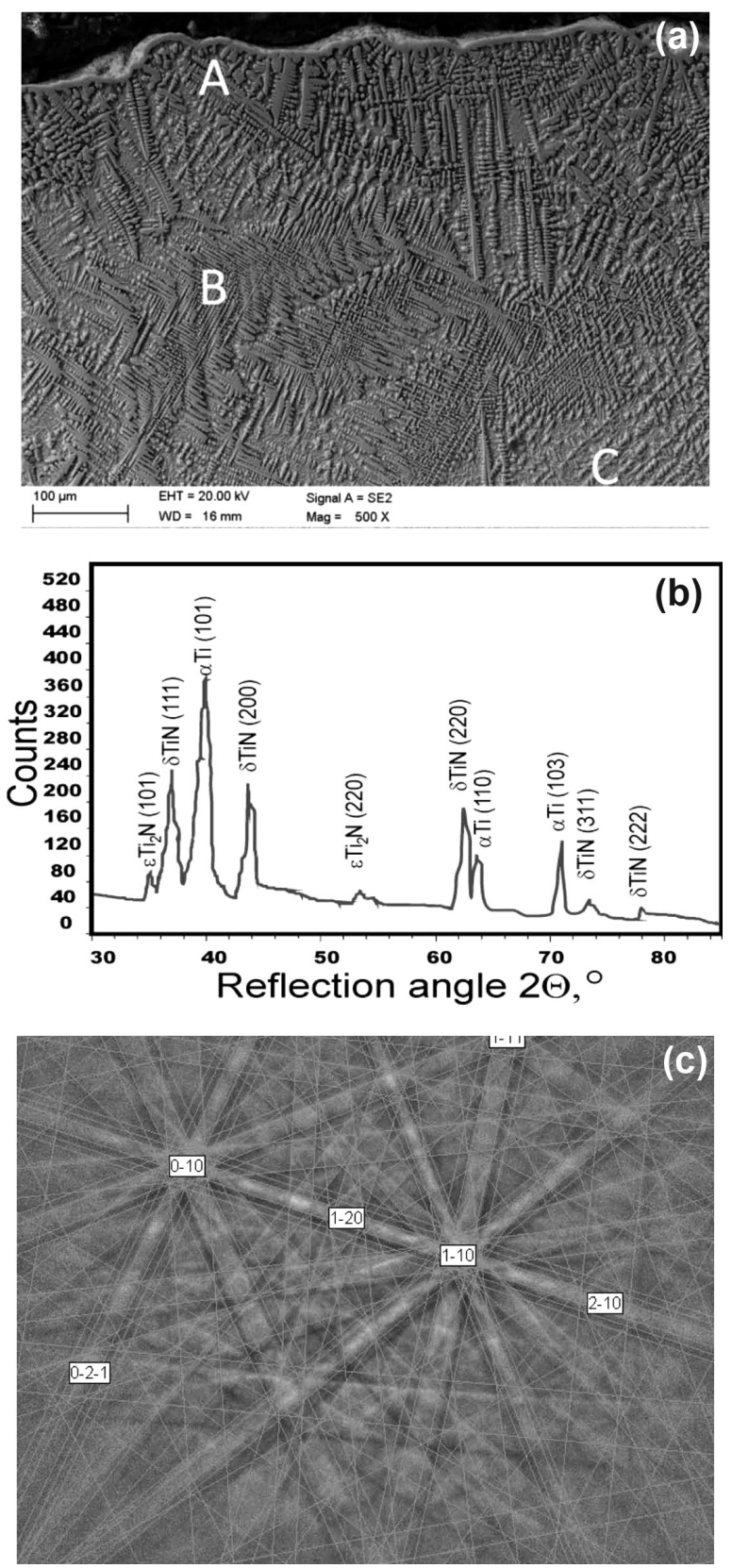

Figure 3: SEM micrograph of the nitrided surface layer SL1, showing the: a) composite structure consisting of $\mathrm{TiN}_{\mathrm{x}}$ dendrites in metallic matrix and b) XRD pattern of the subsurface region A, and c) Kikuchi lines of EBSD analysis in the A region indicating TiN phase type of the composition $\mathrm{N}(50 \%$ of amount fractions $)$ and $\mathrm{Ti}(50 \%$ of amount fractions) 


\section{A. LISIECKI: MECHANISMS OF HARDNESS INCREASE FOR COMPOSITE SURFACE LAYERS ...}

homogenous layer with a thickness from $8 \mu \mathrm{m}$ to a maximum $10 \mu \mathrm{m}$. An analysis of the chemical composition conducted on the depth profile of the cross-section of the surface layers LS1 indicates the presence of only nitrogen and titanium to a depth of approximately $8 \mu \mathrm{m}$, (Figures 7, 8). Despite the large scatter of results, the trend lines show that the nitrogen concentration in this region is up to $40 \%$ (Figure $7 \mathbf{b}$ ). The results of the XRD analysis show the presence of titanium nitrides $\delta$-TiN in the subsurface region (Figure 3b). Additionally, the EBSD analysis indicates that the titanium nitrides have a stoichiometric atomic ratio N/Ti $(50 \%$ of $\mathrm{N}$ and $50 \%$ of Ti), as show in Figure 3c. However, the nitrogen concentration decreases rapidly with the depth, as can be seen in Figure $\mathbf{7 b}$. The structure in the middle region "B" of the surface layer SL1 shows different morphology (Figures 3a, 4). In this region the share of dendrites is considerably smaller, and the orientation of dendrites becomes random. Additionally, the interdendritic spaces are filled with needle-like phases, which were identified by XRD and EBSD analysis as the matrix of martensitic $\alpha$ '-Ti enriched in nitrogen (Figures $\mathbf{3 b}, \mathbf{4 b}$ ). The microhardness in this region falls down gradually to approximately $1400 \mathrm{HV} 0.2$. The XRD spectrum taken from this region indicates presence of $\alpha^{\prime}-\mathrm{Ti}(\mathrm{N}), \delta$-TiN, and also $\varepsilon-\mathrm{Ti}_{2} \mathrm{~N}$ nitrides. Detailed EBSD analysis con-
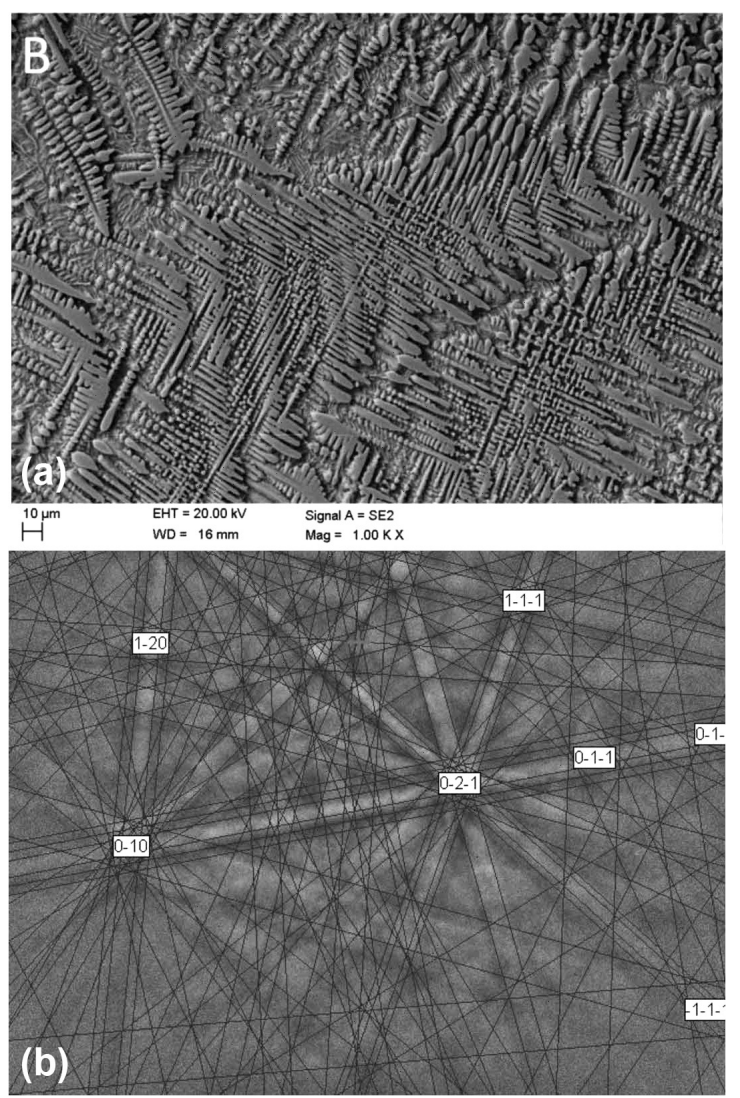

Figure 4: SEM micrograph of: a) the middle region $B$ of the nitrided surface layer SL1 and b) Kikuchi lines of EBSD analysis in the B region indicating $\mathrm{TiN}_{0.61}$ phase type of the composition $\mathrm{N}(37.9 \%$ of amount fractions) and b) $\operatorname{Ti}(62.1 \%$ of amount fractions) firmed the presence of $\varepsilon-\mathrm{Ti}_{2} \mathrm{~N}$ nitrides at the atomic ratio N/Ti $33.3 \%$ of amount fractions of nitrogen and $66.7 \%$ of amount fractions of titanium (Figure 4b). Additionally, the EBSD analysis revealed that the titanium nitrides $\mathrm{TiN}_{X}$ in this region do not have the stoichiometric composition. The precipitations of hard titanium nitrides TiN phase are particularly important because these phases responsible for the enhancement of hardness and wear characteristics of nitrided layers. ${ }^{27}$ The titanium nitride at the stoichiometric ratio of N/Ti (equal to 1) has a face-centred cubic (fcc) structure with the lattice constant $\mathrm{a}=0.4249 \mathrm{~nm}$. However, the lattice parameter depends on the content of nitrogen, but the compound is stable over a wide range of atomic ratio $\mathrm{N} / \mathrm{Ti}$ $(0.6<\mathrm{N} / \mathrm{Ti}<1.16)$, as shown by M. S. Selamat et al. ${ }^{27}$ Similarly the hardness of titanium nitride $\mathrm{TiN}_{\mathrm{X}}$ depends on the atomic ratio N/Ti. That is why different values can be found in the literature. In general, Vickers microhardness values in a range from $2100 \mathrm{HV}$ up to $2400 \mathrm{HV}$ are often reported for the titanium nitride hard coating. However, in the case of coatings or thin films deposited on different substrates the range of microhardness reported in literature is significantly wider. Depending on the applied method of coating deposition, microstructure, especially grain size, columnar vs. equiaxed structure, the thickness of the film, the presence of voids,
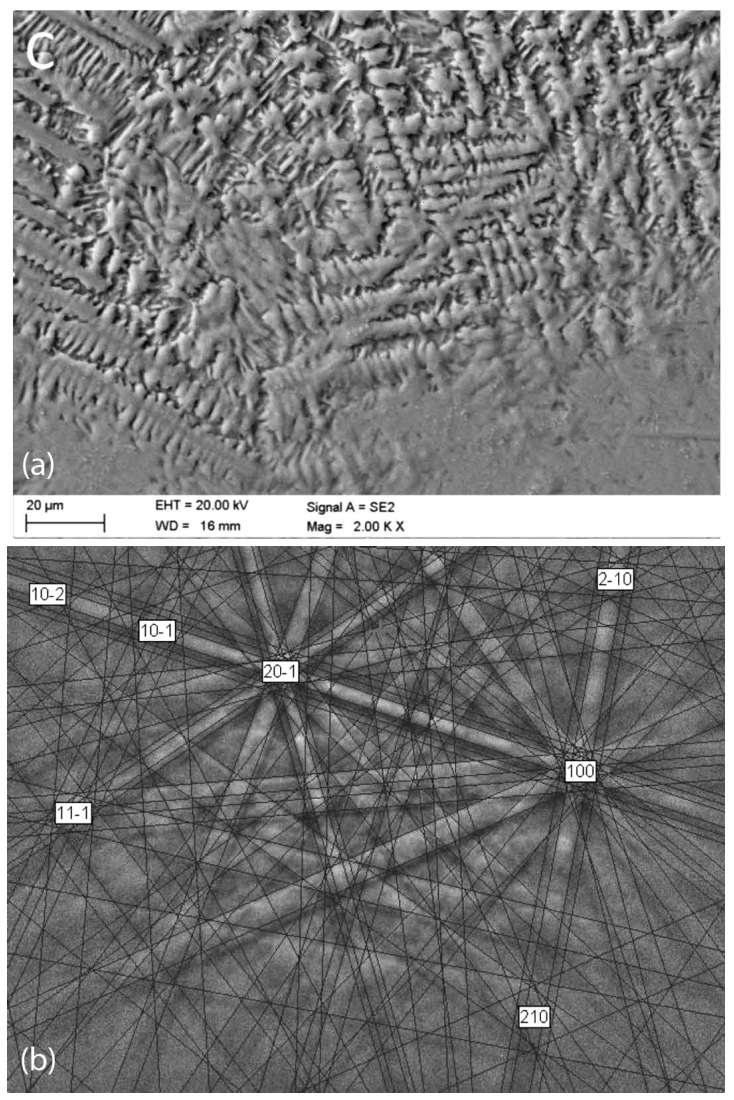

Figure 5: SEM micrograph of: a) the bottom region $C$ of the nitrided surface layer SL1 and b) Kikuchi lines of EBSD analysis in the C region indicating $\mathrm{Ti}_{2} \mathrm{~N}$ phase type of the composition $\mathrm{N}(33.3 \%$ of amount fractions) and $\mathrm{Ti}$ (66.7 \% of amount fractions) 

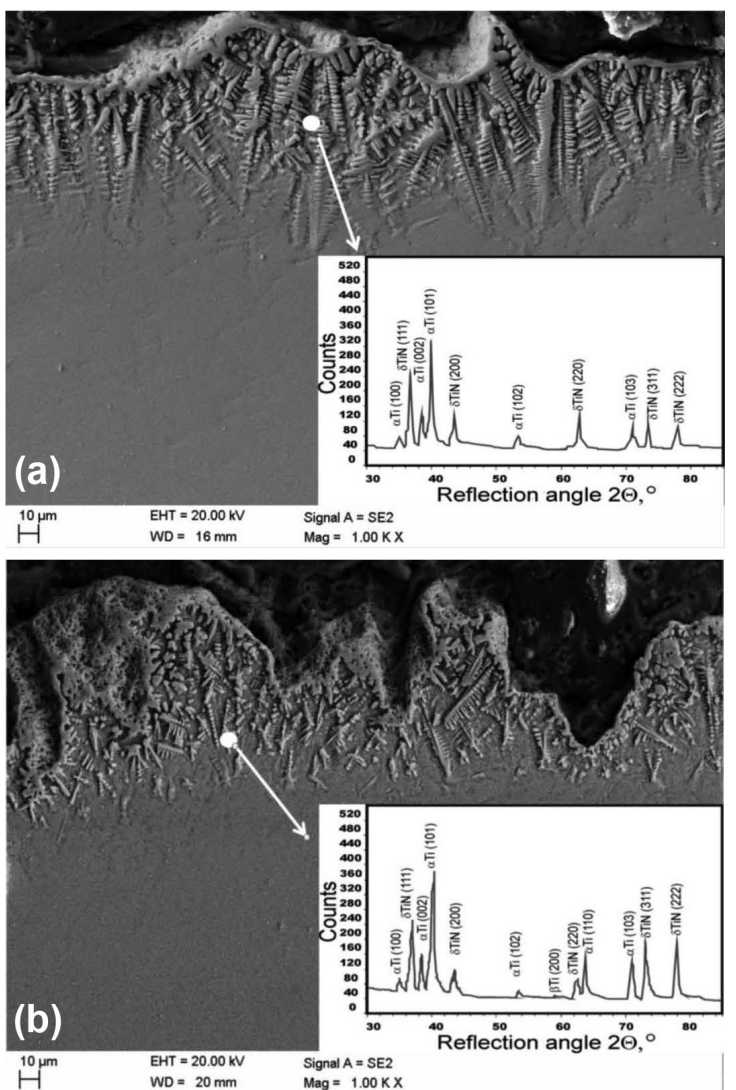

Figure 6: SEM micrographs and XRD patterns of the surface layers: a) SL2, b) SL3

purity, etc., and the microhardness can be significantly higher than $2400 \mathrm{HV}$. On the other hand, the results of hardness nanoindentation of nanocrystalline TiN presented in the literature show significant difference between the single crystal TiN (2900 HV) and the polycrystalline TiN (3200 HV). ${ }^{26,27}$ In the case of the middle region (B) of the surface layer SL1 the atomic ratio of $\mathrm{TiN}_{\mathrm{X}}$ dendrites was determined as $38 \%$ of amount fractions of nitrogen and $62 \%$ of amount fractions of titanium, so the $\mathrm{TiN}_{0.61}$ phase was identified. Additionally, the quantity (volume fraction) of dendritic precipitations decreases with the depth. Thus, the microhardness changes should be considered in relation to both the share of titanium nitrides precipitations, as well as to the atomic ratio N/Ti of the $\mathrm{TiN}_{\mathrm{X}}$ compounds. Since the stoichiometric titanium nitrides $\delta$-TiN have the highest hardness, the share of these nitrides determines the maximum hardness of the surface layers. The third characteristic region $\mathrm{C}$ that can be distinguished in the surface layer SL1 is placed on the bottom, i.e., at the boundary of fusion zone and the heat-affected zone. In this specific region, the amount of titanium nitrides is very small, but the microhardness remains at a high level of about $510 \mathrm{HV} 0.2$. This is because high cooling rates resulted in the formation of martensitic structure of $\alpha^{\prime}-\mathrm{Ti}(\mathrm{N})$. However, the titanium metal matrix is enriched in nitrogen, which is a strong $\alpha$-phase stabilizer and its (a)
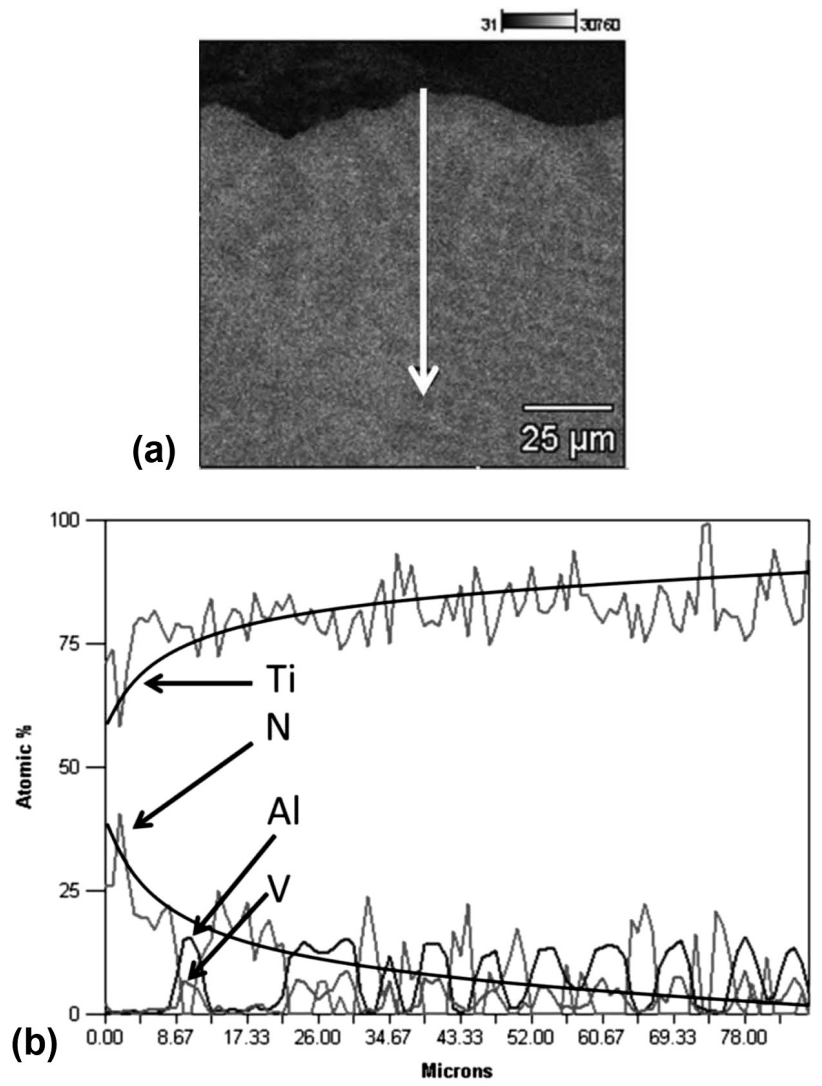

Figure 7: Analysis of the chemical composition on the depth of surface layers LS1 indicates the: a) the line along which the chemical composition was determined b) change in the composition of individual elements

solubility in the $\alpha$-Ti phase reaches $23 \%$ of amount fractions at $1050{ }^{\circ} \mathrm{C}$. Additionally, nitrogen is an interstitial element, which can be considered as strengthening element. The nitrogen distorts the lattice of $\alpha^{\prime}$-Ti matrix by occupying the available interstitial sites in the structure. Thus, during the laser gas nitriding in the liquid state the lattice parameter of $\alpha$ '-Ti phase is affected by both the rapid cooling rates and the nitrogen content dissolved in the titanium matrix. On the other hand, in the region of the heat-affected zone, which reaches the bottom surface of the 3.0-mm-thick sample, the microhardness is in a range from $450 \mathrm{HV} 0.2$ to $500 \mathrm{HV} 0.2$.

The surface layers SL2 and SL3, produced at significantly lower energy inputs of $90 \mathrm{~J} / \mathrm{mm}$ and $60 \mathrm{~J} / \mathrm{mm}$, respectively, show a different morphology (Figure 6). The surface layer SL2 is covered by a homogenous layer of stoichiometric $\delta$-TiN, but the layer is thinner compared to the surface layer SL1. In this case the thickness of the homogenous layer is from $2 \mu \mathrm{m}$ up to $5 \mu \mathrm{m}$. Dendrites perpendicular to the top surface layer extend to a depth of approximately $100 \mu \mathrm{m}$. In contrast to the surface layer SL1, in this case the dendritic nitrides are embedded by the metallic matrix of $\alpha^{\prime}-\operatorname{Ti}(\mathrm{N})$ in the subsurface region (Figure 6a). Therefore, the maximum value of the microhardness measured in the subsurface region is just $1340 \mathrm{HV} 0.2$. Next the microhardness falls 

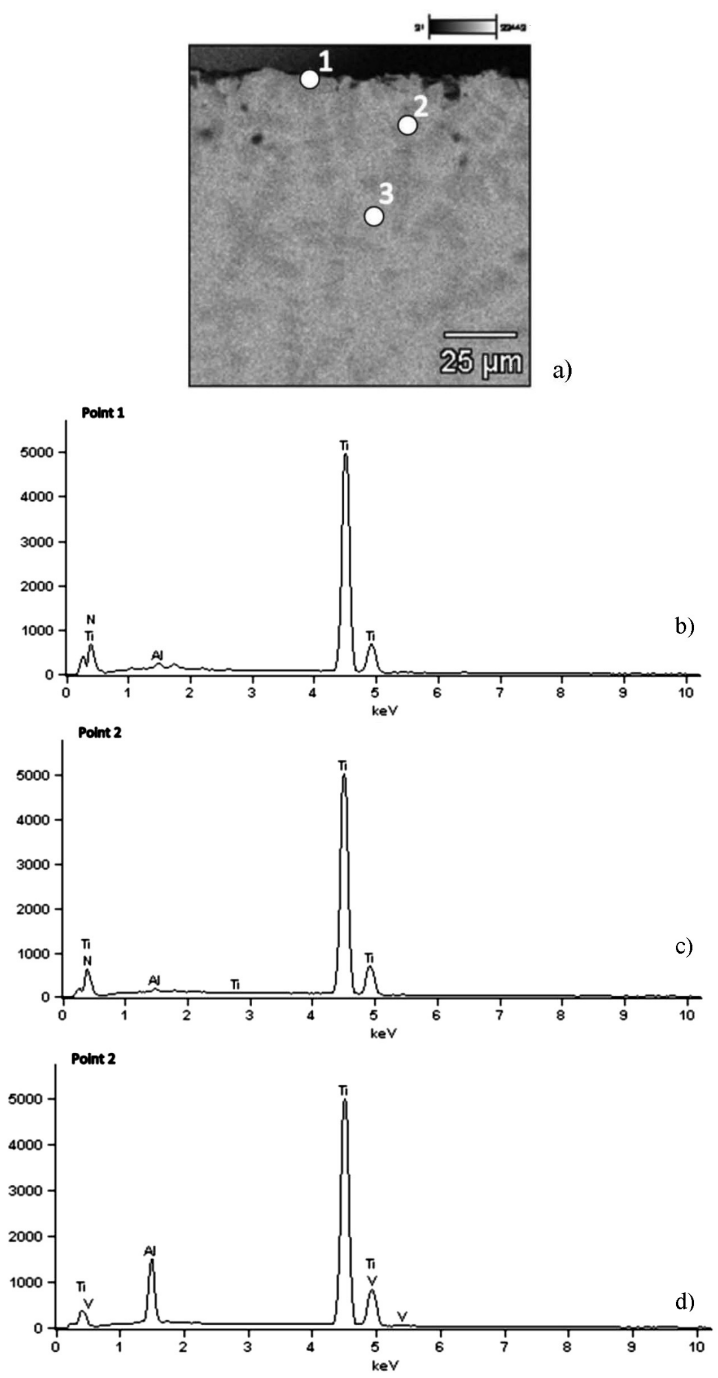

Figure 8: EDS analysis in the subsurface region of the surface layer SL1: a) points of EDS measurements on the cross-section, b) EDS in the point 1, c) EDS in the point 2, d) EDS in the point 3

down to approximately $550 \mathrm{HV} 0.2$ and $400 \mathrm{HV} 0.2$ in the heat-affected zone.

The surface layer SL3 produced at the lowest energy input is also covered by the characteristic golden layer; however, the surface layer is very thin and not tight (Figure $6 \mathbf{b}$ ). The thickness of the layer is from $1 \mu \mathrm{m}$ to $3 \mu \mathrm{m}$. The longest dendrites in the subsurface region have approximately $30 \mu \mathrm{m}$. Additionally, the share of titanium matrix $\alpha^{\prime}-\operatorname{Ti}(\mathrm{N})$ is significantly greater than the dendritic nitrides. Therefore, in this case the highest microhardness of just $820 \mathrm{HV} 0.2$ was determined in the subsurface region, and next the microhardness decreased gradually to the value $500 \mathrm{HV} 0.2$ characteristic for the heat-affected zone.

\section{CONCLUSIONS}

The morphology of surface layers produced by the HPDDL laser surface melting of the Ti6Al4V alloy in a pure nitrogen atmosphere are dependent on the laser processing conditions, such as laser power, beam power density, and scanning speed. However, the highest values of microhardness were measured directly under the top surface for each nitrided surface layer. Depth profiles of microhardness determined on the cross-sections indicate that the microhardness decreases gradually from the subsurface region to the base metal of the titanium alloy, having a microhardness of 330-350 HV.02. The highest value of the microhardness of approximately 2330 HV0.2 was determined in the subsurface region of the surface layer with the greatest depth of $1.6 \mathrm{~mm}$, produced at the highest energy input of $270 \mathrm{~J} / \mathrm{mm}$. The subsurface region consists mainly of closely spaced dendrites oriented perpendicularly to the surface, and identified by XRD and EBSD analysis as titanium nitrides. Additionally, each nitrided surface is covered tightly by a homogenous layer having a thickness up to $10 \mu \mathrm{m}$. The top layer was also identified as the TiN phase at the stoichiometric or near stoichiometric atomic ratio of N/Ti. Below the subsurface region the orientation of dendrites becomes random, and additionally a needle-like phase occurs. The needle-like structure was identified as the matrix of martensitic $\alpha^{\prime}-\mathrm{Ti}(\mathrm{N})$ enriched in nitrogen. The share of the dendritic precipitations and the needle-like matrix structure changes with depth. Moreover, the dendrites concentration decreases with the depth. Thus, it is clear that value of the hardness or the microhardness is correlated with the share of dendritic titanium nitrides and the matrix. However, it was found that the atomic ratio $\mathrm{N} / \mathrm{Ti}$ of the dendritic nitrides is not constant for the nitrided layers produced under different conditions, as well as within a single layer produced at the highest energy input. The EBSD results showed that the dendritic nitrides in the subsurface region of the thicker surface layer are mainly stoichiometric $\delta$-TiN with the atomic ratio $50 \%$ of $\mathrm{N}$ and $50 \%$ of Ti. Since the stoichiometric titanium nitrides exhibit the highest hardness, the share of stoichiometric $\delta$-TiN determines the maximum hardness of the surface layers. The share of stoichiometric $\delta$-TiN decreases rapidly with the depth, which is why the highest microhardness of the composite TiN/Ti layers can be found directly under the top surface, and next the drop of microhardness can be observed.

\section{REFERENCES}

${ }^{1}$ A. Lisiecki, Titanium matrix composite Ti/TiN produced by diode laser gas nitriding, Metals, 5 (2015), 54-69, doi:10.3390/ met5010054

${ }^{2}$ R. Burdzik, L. Konieczny, Z. Stanik, P. Folega, A. Smalcerz, A. Lisiecki, Analysis of impact of chosen parameters on the wear of camshaft, Arch. Metall. Mater., 59 (2014), 957-963, doi:10.2478/ amm-2014-0161

${ }^{3}$ J. Kusiński, S. Kac, A. Kopia, A. Radziszewska, M. RozmusGórnikowska, B. Major, L. Major, J. Marczak, A. Lisiecki, Laser modification of the materials surface layer - a review paper, Bull. Pol. Acad. Sci. Tech. Sci., 60 (2012), 711-728, doi:10.2478/ v10175-012-0083-9 


\section{MATERIALI IN TEHNOLOGIJE/MATERIALS AND TECHNOLOGY (1967-2017) - 50 LET/50 YEARS}

\section{A. LISIECKI: MECHANISMS OF HARDNESS INCREASE FOR COMPOSITE SURFACE LAYERS ...}

${ }^{4}$ J. Górka, Weldability of thermomechanically treated steels having a high yield point, Arch. Metall. Mater., 60 (2015), 469-475

${ }^{5}$ A. Kurc-Lisiecka, W. Ozgowicz, W. Ratuszek, J. Kowalska, Analysis of deformation texture in AISI 304 steel sheets, Sol. St. Phenom., 203-204 (2013), 105-110, doi:10.4028/www.scientific.net/SSP.203204.105

${ }^{6}$ K. Janerka, M. Pawlyta, J. Jezierski, J. Szajnar, D. Bartocha, Carburiser properties transfer into the structure of melted cast iron, J. Mat. Proc. Tech., 214 (2014) 4, 794-801

${ }^{7}$ L. Konieczny, R. Burdzik, B. Lazarz, Application of the vibration test in the evaluation of the technical condition of shock absorbers built into the vehicle, J. Vibroeng, 15 (2013) 4, 2042-2048

${ }^{8}$ A. Czuprynski, J. Górka, M. Adamiak, Examining properties of arc sprayed nanostructured coatings, Metalurgija, 55 (2016) 2, 173-176

${ }^{9}$ L. A. Dobrzański, W. Sitek, M. Krupiński, J. Dobrzański, Computer aided method for evaluation of failure class of materials working in creep conditions, J. Mat. Proc. Tech., 157 (2004), 102-106

${ }^{10}$ J. Bodzenta, A. Kaźmierczak, T. Kruczek, Analysis of thermograms based on FFT algorithm, J. Phys. IV, 129 (2005), 201-206

${ }^{11}$ G. Moskal, A. Grabowski, A. Lisiecki, Laser remelting of silicide coatings on Mo and TZM alloy, Sol. St. Phenom., 226 (2015), 121-126, doi:10.4028/www.scientific.net/SSP.226.121

${ }^{12}$ A. Lisiecki, Welding of thermomechanically rolled steel by $\mathrm{Yb}$ :Yag disk laser, Arch. Metall. Mater., 60 (2015), 2851-2859, doi:10.1515/ amm-2015-0456

${ }^{13}$ A. Lisiecki, R. Burdzik, G. Siwiec, Ł. Konieczny, J. Warczek, P. Folęga, B. Oleksiak, Disk laser welding of car body zinc coated steel sheets, Arch. Metall. Mater., 60 (2015), 2913-2922, doi:10.1515/ amm-2015-0465

${ }^{14}$ A. Lisiecki, Welding of thermomechanically rolled fine-grain steel by different types of lasers, Arch. Metall. Mater., 59 (2014), 1625-1631, doi:10.2478/amm-2014-0276

${ }^{15}$ R. Burdzik, T. Węgrzyn, Ł. Konieczny, A. Lisiecki, Research on influence of fatigue metal damage of the inner race of bearing on vibration in different frequencies, Arch. Metall. Mater., 59 (2014), 1275-1281, doi:10.2478/amm-2014-0218

${ }^{16}$ M. Staszuk, L. A. Dobrzański, T. Tański, W. Kwaśny, M. Musztyfaga-Staszuk, The effect of PVD and CVD coating structures on the durability of sintered cutting edges, Arch. Metall. Mater., 59 (2014), 269-274

${ }^{17}$ A. Grajcar, M. Różański, S. Stano, A. Kowalski, Microstructure characterization of laser-welded Nb-microalloyed silicon-aluminum TRIP steel, J. Mater. Eng. Perform., 23 (2014), 3400-3406
${ }^{18}$ T. Węgrzyn, J. Piwnik, D. Hadryś, R. Wieszała, Car body welding with micro-jet cooling, J.Arch. Mater. Sci. Eng., 49 (2011), 90-94

${ }^{19}$ A. Grajcar, M. Różański, S. Stano, A. Kowalski, B. Grzegorczyk, Effect of heat input on microstructure and hardness distribution of laser welded Si-Al TRIP-type steel, Adv. Mater. Sci. Eng., 2014 (2014), doi.org/10.1155/2014/658947

${ }^{20}$ B. Oleksiak, G. Siwiec, A. Blacha-Grzechnik, J. Wieczorek, The obtained of concentrates containing precious metals for pyrometallurgical processing, Metalurgija 53 (2014), 605-608

${ }^{21} \mathrm{~J}$. Slania, Influence of phase transformations in the temperature ranges of $1250-1000{ }^{\circ} \mathrm{C}$ and $650-350{ }^{\circ} \mathrm{C}$ on the ferrite content in austenitic welds made with T 2312 LRM3 tubular electrode, Arch. Metall. Mater., 50 (2005), 757-767

${ }^{22}$ D. Janicki, Disk laser welding of Armor steel, Arch. Metall. Mater., 59 (2014), 1641-1646, doi:10.2478/amm-2014-0279

${ }^{23}$ B. Slazak, J. Słania, T. Węgrzyn, A. P. Silva, Process stability evaluation of manual metal arc welding using digital signals, Mater. Sci. Forum, 730-732 (2013), 847-852

${ }^{24}$ H. C. Man, Z. D. Cui, T. M. Yue, F. T. Cheng, Cavitation erosion behavior of laser gas nitrided Ti and Ti6Al4V alloy, Mat. Sci. Eng. A, 355 (2003), 167-173, doi:10.1016/S0921-5093(03)00062-5

${ }^{25} \mathrm{~S}$. Mridha, T. N. Baker, Effects of nitrogen gas flow rates on the microstructure and properties of laser-nitrided IMI318 titanium alloy (Ti-4V-6Al), J. Mat. Proc. Tech., 77 (1998), 115-121, doi:10.1016/ S0924-0136(97)00408-1

${ }^{26} \mathrm{C}$. Hu, T.N. Baker, The importance of preheat before laser nitriding a Ti-6Al-4V alloy, Mat. Sci. Eng. A, 265 (1999), 268-275, doi:10.1016/S0921-5093(98)01135-6

${ }^{27}$ M. S. Selamat, T. N. Baker, L. M. Watson, Study of the surface layer formed by the laser processing of Ti-6Al-4V alloy in a dilute nitrogen environment, J. Mat. Proc. Tech., 113 (2001), 509-515, doi:10.1016/S0924-0136(01)00595-7

${ }^{28}$ W. Pakieła, T. Tański, Z. Brytan, K. Labisz, The influence of laser alloying on the structure and mechanical properties of AlMg5Si2Mn surface layers, Appl. Phys. A, 122 (2016), 352, doi:10.1007/s00339016-9834-z

${ }^{29} \mathrm{M}$. Bonek, The investigation of microstructures and properties of high speed steel HS6-5-2-5 after laser alloying, Arch. Metall. Mater., 59 (2014), 1647-1651, doi:10.2478/amm-2014-0280 